\title{
Communication
}

\section{Further Insights into the Toxicity of Bacillus cytotoxicus Based on Toxin Gene Profiling and Vero Cell Cytotoxicity Assays}

\author{
Johanna Burtscher $^{1, *(\mathbb{D}}$, Danai Etter ${ }^{2}\left(\mathbb{D}\right.$, Michael Biggel $^{2}\left(\mathbb{D}\right.$, Janine Schlaepfer $^{2}$ and Sophia Johler ${ }^{2}(\mathbb{D}$ \\ 1 Institute of Food Science, BOKU—University of Natural Resources and Life Sciences Vienna, \\ 1190 Vienna, Austria \\ 2 Institute for Food Safety and Hygiene, Vetsuisse Faculty, University of Zürich, 8057 Zurich, Switzerland; \\ danai.etter@uzh.ch (D.E.); michael.biggel@uzh.ch (M.B.); janine.schlaepfer@uzh.ch (J.S.); \\ sophia.johler@uzh.ch (S.J.) \\ * Correspondence: johanna.burtscher@boku.ac.at
}

Citation: Burtscher, J.; Etter, D.; Biggel, M.; Schlaepfer, J.; Johler, S. Further Insights into the Toxicity of Bacillus cytotoxicus Based on Toxin Gene Profiling and Vero Cell

Cytotoxicity Assays. Toxins 2021, 13, 234. https://doi.org/10.3390/ toxins13040234

Received: 22 February 2021

Accepted: 22 March 2021

Published: 24 March 2021

Publisher's Note: MDPI stays neutral with regard to jurisdictional claims in published maps and institutional affiliations.

Copyright: (c) 2021 by the authors. Licensee MDPI, Basel, Switzerland. This article is an open access article distributed under the terms and conditions of the Creative Commons Attribution (CC BY) license (https:/ / creativecommons.org/licenses/by/ $4.0 /)$.

\begin{abstract}
Bacillus cytotoxicus belongs to the Bacillus cereus group that also comprises the foodborne pathogen Bacillus cereus sensu stricto, Bacillus anthracis causing anthrax, as well as the biopesticide Bacillus thuringiensis. The first B. cytotoxicus was isolated in the context of a severe food poisoning outbreak leading to fatal cases of diarrheal disease. Subsequent characterization of the outbreak strain led to the conclusion that this Bacillus strain was highly cytotoxic and eventually resulted in the description of a novel species, whose name reflects the observed toxicity: B. cytotoxicus. However, only a few isolates of this species have been characterized with regard to their cytotoxic potential and the role of $B$. cytotoxicus as a causative agent of food poisoning remains largely unclear. Hence, the aim of this study was to gain further insights into the toxicity of B. cytotoxicus. To this end, 19 isolates were obtained from mashed potato powders and characterized by toxin gene profiling and Vero cell cytotoxicity assays. All isolates harbored the cytK1 (cytotoxin K1) gene and species-specific variants of the nhe (non-hemolytic enterotoxin) gene. The isolates exhibited low or no toxicity towards Vero cells. Thus, this study indicates that the cytotoxic potential of B. cytotoxicus may be potentially lower than initially assumed.
\end{abstract}

Keywords: $c y t K$; enterotoxins; Vero cell assay; mashed potato powder; nhe variant

Key Contribution: A high prevalence (95\%) of B. cytotoxicus in mashed potato powder was observed. Isolates from mashed potato powder harbored $c y t K 1$ and nhe genes, but exhibited no or low cytotoxicity in a Vero cell assay.

\section{Introduction}

B. cytotoxicus belongs to the B. cereus group. This group of endospore-forming bacteria comprises several closely related species that differ significantly in toxicity and pathogenicity potential including probiotic strains, plant growth promoters and biopesticides as well as highly toxic strains, occasionally causing fatalities [1,2]. Several members of the $B$. cereus group have been linked to emetic or diarrheal foodborne illnesses. The causative agents of gastrointestinal symptoms are different toxins. The intake of the heat-stable toxin cereulide, which is encoded by the ces locus, causes emesis and nausea and its presence is attributed to the growth of emetic B. cereus in food [2]. Heat-labile toxins, in contrast, such as non-hemolytic enterotoxins (Nhe), hemolysin BL ( $\mathrm{Hbl})$, and cytotoxin $\mathrm{K}(\mathrm{CytK})$, lead to diarrheal toxico-infections, as toxin production occurs in the small intestine [2,3]. B. cytotox$i c u s$ is known to cause diarrheal symptoms and has not been linked to emetic illness. It represents a relatively homogenous species, which is clearly distinguishable from other members of the B. cereus group [4,5]. The first documented isolation of B. cytotoxicus from vegetable puree took place in 1998 in France during a severe food poisoning outbreak that resulted in 44 ill individuals, including three fatalities [6]. Since then, further cases of food 
poisoning associated with vegetable purees have been described $[7,8]$. However, at the time of sampling, the isolates were classified as B. cereus and only later assigned to B. cytotoxicus after the introduction of the novel species in 2013 [7]. B. cytotoxicus is characterized by its thermotolerance, which seems to confer a growth advantage in processed foods, such as vegetable purees. Furthermore, the absence of starch hydrolysis, the dependency on tryptophan for growth, and the presence of a specific cytK1 variant of the gene encoding cytotoxin $\mathrm{K}$ are typical attributes of this species [7]. CytK1 is one of two known genetic variants of cytotoxin $\mathrm{K}$, a pore-forming toxin with necrotic and hemolytic activity [9]. Fagerlund, et al. [10] observed higher toxicity towards human intestinal CaCo-2 cells and Vero cells for CytK1 than for CytK2, which is produced by other members of the B. cereus group. As a consequence, they concluded that the high cytotoxic activity of CytK1 may have caused the high virulence of the B. cytotoxicus outbreak strain from France. However, present data on the cytotoxicity of this species are ambiguous and indicate strain-specific differences. While the high toxicity of strains associated with food poisoning incidents was mostly confirmed [9], studies using randomly isolated strains from food yielded varying results. For instance, Vero cell cytotoxicity assays testing isolates from powdered mashed potato products revealed low or no cytotoxicity for eight strains, thus indicating that the toxic potential of $B$. cytotoxicus may have been overestimated [11]. In contrast, one isolate exhibited exceptionally high toxicity, significantly surpassing the toxicity of a B. cereus sensu lato outbreak strain that was used as a reference [11]. To our knowledge, the cytotoxicity data of B. cytotoxicus are currently limited to 12 isolates. Therefore, further data are pivotal to assess the health risk originating from the presence of B. cytotoxicus in food. Hence, within this study, we aimed to sharpen our understanding of the cytotoxic potential of this species. To this end, we isolated B. cytotoxicus strains from mashed potato powders in order to characterize their toxin genes and their cytotoxic potential.

\section{Results and Discussion}

\subsection{Prevalence in Mashed Potato Powders}

We detected at least one isolate of $B$. cereus sensu lato in each tested brand of mashed potato powder and found B. cytotoxicus in 19 out of the 20 (95\%) purchased samples (see Table 1). The high prevalence of $B$. cytotoxicus in mashed potato powders revealed within this study is in good agreement with the results of previous studies on mashed potatoes, other heat-treated potato products, or products made thereof [11-14]. The ecological niche of $B$. cytotoxicus and the contamination pathway of potato products, however, remain unclear. Indeed, the first isolation of this species from a natural habitat (geothermal areas) was published only recently, but it does not provide any indication of potential food contamination pathways [15]. Stevens, et al. [4] revealed that B. cytotoxicus harbors a putative hydroxyphenylalanine ( $h p a)$ operon, which is absent in the genomes of other $B$. cereus group members. They concluded that the presence of this operon may confer an evolutionary advantage to $B$. cytotoxicus as it enables the species to metabolize aromatic compounds and to potentially inhibit Gram-negatives in the intestine by producing the inhibiting agent para-cresol. Furthermore, hpa-encoded pathways are often associated with soil bacteria, thus indicating soil as the ecological niche of B. cytotoxicus [4]. Moreover, it can be assumed that the heat treatment applied during the production of dried potato products also provides a selective advantage to the thermotolerant B. cytotoxicus. In addition, the growth of B. cytotoxicus in mashed potatoes has been reported after keeping cooked puree at room temperature for several hours [12]. This is particularly relevant because vegetable purees are often served in mass catering facilities, where temperature control during food handling is crucial, albeit challenging. The risk of B. cytotoxicus intoxications associated with mass catering facilities is also reflected in epidemiological data. For instance, all five registered foodborne outbreaks in France from 2007 to 2014 due to B. cytotoxicus happened in school or staff canteens, retirement homes, or community facilities [16]. However, consideration must be given to the fact that $B$. cytotoxicus as a causative agent of foodborne illness may be underreported in other settings due to the generally rather mild and self- 
limiting symptoms that did not require medical attention or further microbiological tests [8]. Moreover, in the case of microbiological food analyses, members of the B. cereus group are not usually further differentiated, which partly explains the limited amount of data at the species level [17]. Therefore, it is all the more important to add cytotoxicity data to the body of knowledge, thus improving our understanding of the toxic potential of B. cytotoxicus in food.

Table 1. Overview of toxin genes detected by PCR (polymerase chain reaction) in strains isolated from mashed potato powders (sample numbers 1-20) of brands A-G and results of a WST-1 bioassay using Vero cells shown as normalized reciprocal cytotoxicity titers.

\begin{tabular}{|c|c|c|c|c|c|c|c|c|c|c|}
\hline \multirow[b]{2}{*}{$\begin{array}{l}\text { Sample } \\
\text { Number }\end{array}$} & \multirow[b]{2}{*}{ Strain ID } & \multirow[b]{2}{*}{ Species } & \multirow[b]{2}{*}{ Brand } & \multicolumn{5}{|c|}{ Toxin Genes } & \multicolumn{2}{|c|}{$\begin{array}{c}\text { Enterotoxin Production in Vero Cell } \\
\text { Assay }\end{array}$} \\
\hline & & & & $n h e^{1}$ & $n h e_{\mathrm{Bcyt}}$ & $h b l$ & cytK & ces & $\begin{array}{c}\text { Normalized } \\
\text { Reciprocal Titer } 2\end{array}$ & $\begin{array}{c}\text { Standard } \\
\text { Deviation }\end{array}$ \\
\hline 1 & CH_301 & B. cytotoxicus & $\mathrm{A}$ & - & + & - & $+(c y t K 1)$ & - & 0.00 & 0.00 \\
\hline 2 & CH_302 & B. cytotoxicus & B & - & + & - & $+($ cytK1) & - & 0.00 & 0.00 \\
\hline 3 & CH_303 & B. cytotoxicus & A & - & + & - & $+(c y t K 1)$ & - & 0.03 & 0.03 \\
\hline 4 & CH_304 & B. cytotoxicus & $\mathrm{C}$ & - & + & - & $+($ cytK1) & - & 0.03 & 0.03 \\
\hline 5 & CH_305 & B. cytotoxicus & $\mathrm{D}$ & - & + & - & $+(c y t K 1)$ & - & 0.15 & 0.15 \\
\hline 6 & CH_306 & B. cytotoxicus & B & - & + & - & $+(c y t K 1)$ & - & 0.00 & 0.00 \\
\hline 7 & CH_307 & B. cytotoxicus & B & - & + & - & $+($ cytK1) & - & 0.00 & 0.00 \\
\hline 8 & CH_308 & B. cytotoxicus & $\mathrm{D}$ & - & + & - & $+($ cytK1) & - & 0.07 & 0.07 \\
\hline 9 & CH_309 & B. cytotoxicus & $\mathrm{C}$ & - & + & - & $+(c y t K 1)$ & - & 0.00 & 0.00 \\
\hline 10 & CH_310 & B. cytotoxicus & $\mathrm{E}$ & - & + & - & $+($ cytK1) & - & 0.00 & 0.00 \\
\hline 11 & CH_311 & B. cytotoxicus & $\mathrm{A}$ & - & + & - & $+(c y t K 1)$ & - & 0.00 & 0.00 \\
\hline 12 & CH_312 & B. cytotoxicus & $\mathrm{F}$ & - & + & - & $+($ cytK1) & - & 0.00 & 0.00 \\
\hline 13 & CH_313 & B. cytotoxicus & $\mathrm{F}$ & - & + & - & $+(\operatorname{cytK} 1)$ & - & 0.01 & 0.01 \\
\hline 14 & CH_314 & B. cytotoxicus & $\mathrm{C}$ & - & + & - & $+(\operatorname{cytK} 1)$ & - & 0.01 & 0.01 \\
\hline 15 & CH_315 & B. cytotoxicus & $\mathrm{B}$ & - & + & - & $+(c y t K 1)$ & - & 0.02 & 0.02 \\
\hline 16 & CH_316 & B. cytotoxicus & A & - & + & - & $+(c y t K 1)$ & - & 0.08 & 0.06 \\
\hline 17 & CH_317 & B. cytotoxicus & $\mathrm{E}$ & - & + & - & $+($ cytK1) & - & 0.03 & 0.03 \\
\hline 18 & CH_318 & B. cytotoxicus & $\mathrm{G}$ & - & + & - & $+(\operatorname{cytK} 1)$ & - & 0.09 & 0.09 \\
\hline 19 & CH_319 & $\begin{array}{l}\text { B. cereus sensu } \\
\text { lato }\end{array}$ & B & + & - & - & - & - & n.a. & n.a. \\
\hline 20 & CH_647 & B. cytotoxicus & $\mathrm{D}$ & - & + & - & $+(c y t K 1)$ & - & 0.32 & 0.09 \\
\hline n.a. & $\begin{array}{c}\mathrm{NVH} \\
0075-95^{2}\end{array}$ & $\begin{array}{l}\text { B. cereus sensu } \\
\text { stricto }\end{array}$ & n.a. & + & - & - & - & - & 1.00 & 0.63 \\
\hline
\end{tabular}

+ positive, - negative, n.a. not available. ${ }^{1}$ As the nhe gene variant of $B$. cytotoxicus was not detected using standard primers targeting the nhe gene of B. cereus sensu lato, primers specifically detecting the $n h e$ variant occurring in B. cytotoxicus strains were used (nhe ${ }_{\mathrm{Bcyt}}$ ). ${ }^{2}$ Reciprocal titers are provided as absolute values normalized using the absolute value of the highly cytotoxic $B$. cereus sensu stricto reference strain NVH 0075-95 of the same Vero cell run. ${ }^{3}$ Two independent Vero cell runs were performed, each including two technical replicates of each dilution series per Bacillus strain.

\subsection{Toxin Gene Profiling}

The 19 isolates recovered from different mashed potato powder samples of seven distinct brands showed homogenous toxin profiles (Table 1). Each isolate harbored the gene $c y t K 1$, whereas the genes $c y t K 2, h b l$, and ces were not detected. This toxin profile in B. cytotoxicus is consistent with previous studies. So far, no B. cytotoxicus strains have been discovered that harbor the ces gene encoding cereulide and the $c y t K 1$ variant of the $c y t K$ gene has been determined as a characteristic feature of B. cytotoxicus $[7,11,16]$. Cytotoxin $\mathrm{K}$ is a pore-forming, necrotic, and hemolytic protein that was initially isolated from an outbreak strain that had been linked to severe food poisoning [6]. The high virulence of this outbreak strain was at least partly attributed to the greater cytotoxic activity of CytK1 towards Vero cells compared to CytK2 [10]. However, the later discovery of non-cytotoxic strains harboring the cytK1 gene led to the assumption that the detection of this gene variant does not necessarily indicate highly cytotoxic strains $[9,18]$.

It is known that while all $B$. cereus sensu lato harbor nhe, classical nhe primers fail

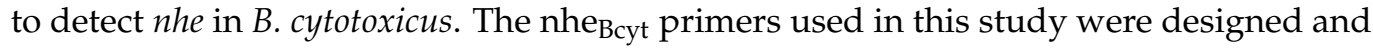
validated based on all publicly available and whole genome sequences of B. cytotoxicus. In preliminary PCR runs using the new primers, the presence of the nhe gene variant of 
B. cytotoxicus was confirmed in 13 additional B. cytotoxicus isolates from the internal culture collection (data not shown). The the gene variant of the reference strain B. cereus sensu stricto was not amplified (see Table 1).

Across the tested strain set within this study, the nhe gene encoding the non-hemolytic enterotoxin complex Nhe was not detected using standard primers targeting the nhe gene of $B$. cereus sensu lato [19]. However, all tested strains were positive for the nhe gene using primers $\left(\right.$ nhe $\left._{\mathrm{Bcyt}}\right)$. This is consistent with the finding that the nhe gene variant of B. cytotoxicus yields only about $80 \%$ identity in protein sequence compared with the previously described Nhe toxins in B. cereus [9]. The presence of the nhe operon in B. cytotoxicus also corroborates previous observations that nearly $100 \%$ of enteropathogenic B. cereus strains harbor this gene $[8,20]$. The primers described within this study appear to be a useful tool allowing for nhe screening in B. cytotoxicus in future studies. However, although the presence of enterotoxin genes, such as cytK1 and nhe, may indicate potential toxic effects, it is well known that the toxic activity of a strain cannot be derived from the sole presence of enterotoxin genes $[9,11]$. Indeed, toxin production is a complex process that requires the coordinated action of several factors, including transcriptional, posttranscriptional and posttranslational regulatory mechanisms [21].

\subsection{Vero Cell Cytotoxicity}

A Vero cell assay was performed to investigate a potential cytotoxic impact. Vero cells were used due to the wide range of experience in testing B. cereus cytotoxicity using this cell type and a higher susceptibility of Vero cells towards Nhe than towards $\mathrm{Hbl}$, which has hitherto seemed to be irrelevant in B. cytotoxicus. Indeed, Nhe seems to explain most of the cytotoxic potential in Vero cell assays and appears to be a good indicator for the diarrheic potential of B. cereus because food poisoning strains tend to produce high levels of this enterotoxin [20].

Reciprocal titers obtained in the Vero cell assay are shown in Table 1. No cytotoxic effect was observed for eight of the B. cytotoxicus strains ( $\mathrm{CH} 301, \mathrm{CH} 302, \mathrm{CH} 306, \mathrm{CH} 307$, CH 309, CH 310, CH 311, CH 312). Eleven strains exhibited cytotoxic effects, albeit all strains are considered to be low-level enterotoxin producers. This outcome supports the assumption of Heini et al. [11] — that most B. cytotoxicus strains isolated from food seem to be non-toxic with a few highly cytotoxic exceptions-as well as the hypothesis of Fagerlund, et al. [9] - that the cytotoxicity of this species may have been overestimated. As information about the cytotoxicity of B. cytotoxicus is still extremely scarce, the current study adds valuable Vero cytotoxicity data to the current state of knowledge.

It has recently become evident that several other parameters may contribute to food toxico-infections caused by B. cereus sensu lato. This includes consumed foodstuff and stomach passage as well as strain-specific characteristics and virulence factors, such as; spore germination, motility, adhesion, and secreted enzymes $[2,8,22,23]$. Further research into the role of these factors and the hazardous potential of a strain or meal is crucial for risk assessment.

\section{Conclusions}

In conclusion, this study provides further insights into the cytotoxicity of the rarely explored species B. cytotoxicus. We observed a high prevalence of B. cytotoxicus in mashed potato powders and demonstrated that a majority of isolates show no or low cytotoxicity towards Vero cells, despite the presence of enterotoxin genes cytK1 and nhe. This corroborates previous assumptions that the hazardous potential of this species may be lower than initially assumed. Nevertheless, it has to be kept in mind that the thermotolerant spore former B. cytotoxicus can endure the production process of dehydrated products and is able to grow into hazardous concentrations when these products are held at improper temperatures. The results of this study contribute towards a better understanding and an improved risk assessment of B. cytotoxicus. 


\section{Materials and Methods}

\subsection{Isolation of B. cytotoxicus from Mashed Potato Powder}

A total of 20 mashed potato powders from 7 different brands (A-G) had been purchased from Swiss supermarkets in 2018 and 2020 (see Table 1). Two isolation procedures were performed in parallel and in accordance with the protocols described by Heini, et al. [11] and Contzen, et al. [14]. These protocols included different media for enrichment (buffered peptone water (Oxoid, Basel, CH) and CGY Medium [24]), streaking (Mossel agar and sheep blood agar), and different incubation temperatures $\left(37\right.$ and $46{ }^{\circ} \mathrm{C}$ ). Characteristic colonies (rough and dry showing hemolysis on blood agar or rough and dry with a pink background surrounded by an egg yolk precipitate on Mossel agar) were selected and subcultured in CGY broth. Pure cultures were stored at $-80{ }^{\circ} \mathrm{C}$ after the addition of $20 \%(v / v)$ glycerol.

\subsection{DNA Extraction and Toxin Gene Profiling}

Prior to DNA extraction, presumptive B. cytotoxicus strains were reactivated by streaking them on sheep blood or Mossel agar. Then, single colonies were chosen to prepare overnight cultures in CGY broth. After incubation at $37^{\circ} \mathrm{C}$, DNA was extracted using the DNeasy Blood and Tissue Kit (Qiagen, Hombrechtikon, Switzerland). Obtained isolates were screened for the presence of $n h e$ (non-hemolytic enterotoxin), cytK (cytotoxin K), ces (cereulide) and $h b l$ (hemolysin BL) genes in a multiplex PCR assay described by EhlingSchulz et al. [19]. Further discrimination between cytK1 and cytK2 was achieved using the primers published by Guinebretiere et al. [25]. Because sequence analysis of publicly available genomes showed that the nhe gene of $B$. cytotoxicus differs from other members of the $B$. cereus group, a primer pair were designed to specifically target the nhe operon of B. cytotoxicus. The primer nhe $e_{\text {BcytF }}\left(5^{\prime}\right.$-CGG AAG CAG AGG TAA CAG AAA- $\left.3^{\prime}\right)$ binds to the $n$ he $A$ gene and the primer nhe ${ }_{\text {BcytR }}\left(5^{\prime}\right.$ - GTG GCT ACA GAG GAA CCA ATAA-3') binds to the nhe $B$ gene, yielding an amplicon length of $1045 \mathrm{bp}$. For all PCR reactions, the GoTaq G2 Hot Start master mix (Promega, Madison, USA) was used with the following standard PCR program: initial denaturation at $95^{\circ} \mathrm{C}$ for $2 \mathrm{~min}, 30$ cycles of denaturation at $95^{\circ} \mathrm{C}$ for $45 \mathrm{~s}$, annealing at $51{ }^{\circ} \mathrm{C}$ for $45 \mathrm{~s}$, and extension at $72{ }^{\circ} \mathrm{C}$ for $2 \mathrm{~min}$, followed by a final extension of $5 \mathrm{~min}$ at $72{ }^{\circ} \mathrm{C}$. If necessary, annealing temperatures were adjusted to the primer system and the extension time was adapted to the expected amplicon length.

\subsection{Vero Cell Cytotoxicity Assay}

Cell-free supernatants were produced using CGY broth. First, an overnight culture of each B. cytotoxicus strain was prepared in $3 \mathrm{~mL}$ of CGY broth (incubation at $30^{\circ} \mathrm{C}$, shaking at $150 \mathrm{rpm}$ ). Grown cultures were then inoculated into $30 \mathrm{~mL}$ of CGY in an Erlenmeyer flask at an $\mathrm{OD}_{600}$ of 0.05 and incubated at $30^{\circ} \mathrm{C}$ (shaking at $150 \mathrm{rpm}$ ) until an $\mathrm{OD}_{600}$ of 7 was reached. Subsequently, bacterial biomass was removed by centrifuging $5 \mathrm{~mL}$ of the culture at $11,000 \mathrm{rpm}$ for $10 \mathrm{~min}$ at $4{ }^{\circ} \mathrm{C}$ and by passing the obtained supernatant through a sterile filter $(0.2 \mu \mathrm{m}$ pore size). Aliquots of $1 \mathrm{~mL}$ sterile supernatant were supplemented with $10 \mu \mathrm{L}$ of $0.1 \mathrm{M}$ EDTA-Na 2 and stored at $-80^{\circ} \mathrm{C}$. The cytotoxicity of the supernatants was assessed in a Vero cell assay using WST-1 as described by Moravek, et al. [20]. In brief, serial dilutions of the supernatants were distributed into microtiter plates containing Vero cell suspensions ( $10^{4}$ cells per well) in Dulbecco's modified Eagle medium supplemented with $1 \%$ fetal calf serum and $0.4 \%$ penicillin-streptomycin $(5000 \mathrm{U} / \mathrm{mL})$. After incubation for $24 \mathrm{~h}$ at $37^{\circ} \mathrm{C}$ and $5 \% \mathrm{CO}_{2}$, the extinction of the produced formazan dye from WST- 1 was measured at $450 \mathrm{~nm}$ in order to determine the mitochondrial activity of viable cells. The obtained data were transformed into a dose-response curve, which was used to calculate the $50 \%$ loss of mitochondrial activity, shown as reciprocal cytotoxicity titers. For each strain, two independent Vero cell assays were performed, each including two technical replicates of each dilution series per strain. The food poisoning $B$. cereus sensu stricto strain NVH 0075-95 was used as a highly cytotoxic reference strain. Strains were classified into toxicity levels according to Jeßberger, et al. [21] and cutoffs were normalized based on the mean of the reference strain according to Johler, et al. [1]. Absolute cytotoxicity values $<0.4$ 
were considered as low-level, values from 0.4 to 0.8 were considered as mid-level, and values $>0.8$ were considered as high-level enterotoxin producers.

Author Contributions: Conceptualization, S.J.; Data curation, J.B., D.E., S.J.; Investigation, J.B., D.E., M.B., J.S.; writing—original draft preparation, J.B.; writing-review and editing, J.B., S.J., D.E., M.B., J.S.; visualization, J.B.; supervision, S.J. All authors have read and agreed to the published version of the manuscript.

Funding: The authors thank the FEMS (Federation of European Microbiological Societies) for supporting this project with a Research and Training Grant. Open access funding provided by BOKU Vienna Open Access Publishing Fund.

Institutional Review Board Statement: Not applicable.

Informed Consent Statement: Not applicable.

Data Availability Statement: Not applicable.

Conflicts of Interest: The authors declare no conflict of interest.

\section{References}

1. Johler, S.; Kalbhenn, E.M.; Heini, N.; Brodmann, P.; Gautsch, S.; Bağcioğlu, M.; Contzen, M.; Stephan, R.; Ehling-Schulz, M. Enterotoxin production of Bacillus thuringiensis isolates from biopesticides, foods, and outbreaks. Front. Microbiol. $2018,9$. [CrossRef]

2. Ehling-Schulz, M.; Lereclus, D.; Koehler, T.M. The Bacillus cereus group: Bacillus species with pathogenic potential. Microbiol. Spectr. 2019, 7. [CrossRef]

3. Stenfors Arnesen, L.P.; Fagerlund, A.; Granum, P.E. From soil to gut: Bacillus cereus and its food poisoning toxins. FEMS Microbiol. Rev. 2008, 32, 579-606. [CrossRef]

4. Stevens, M.J.A.; Tasara, T.; Klumpp, J.; Stephan, R.; Ehling-Schulz, M.; Johler, S. Whole-genome-based phylogeny of Bacillus cytotoxicus reveals different clades within the species and provides clues on ecology and evolution. Sci. Rep. 2019, 9. [CrossRef]

5. Carroll, L.M.; Wiedmann, M.; Kovac, J. Proposal of a taxonomic nomenclature for the Bacillus cereus group which reconciles genomic definitions of bacterial species with clinical and industrial phenotypes. MBio 2020, 11. [CrossRef] [PubMed]

6. Lund, T.; De Buyser, M.L.; Granum, P.E. A new cytotoxin from Bacillus cereus that may cause necrotic enteritis. Mol. Microbiol. 2000, 38, 254-261. [CrossRef] [PubMed]

7. Guinebretière, M.H.; Auger, S.; Galleron, N.; Contzen, M.; de Sarrau, B.; de Buyser, M.L.; Lamberet, G.; Fagerlund, A.; Granum, P.E.; Lereclus, D.; et al. Bacillus cytotoxicus sp. nov. is a novel thermotolerant species of the Bacillus cereus group occasionally associated with food poisoning. Int. J. Syst. Evol. Microbiol. 2013, 63, 31-40. [CrossRef]

8. Jessberger, N.; Dietrich, R.; Granum, P.E.; Märtlbauer, E. The Bacillus cereus Food Infection as Multifactorial Process. Toxins 2020, 12, 701. [CrossRef] [PubMed]

9. Fagerlund, A.; Brillard, J.; Fürst, R.; Guinebretière, M.H.; Granum, P.E. Toxin production in a rare and genetically remote cluster of strains of the Bacillus cereus group. BMC Microbiol. 2007, 7, 1-8. [CrossRef]

10. Fagerlund, A.; Ween, O.; Lund, T.; Hardy, S.P.; Granum, P.E. Genetic and functional analysis of the $c y t K$ family of genes in Bacillus cereus. Microbiology 2004, 150, 2689-2697. [CrossRef] [PubMed]

11. Heini, N.; Stephan, R.; Ehling-Schulz, M.; Johler, S. Characterization of Bacillus cereus group isolates from powdered food products. Int. J. Food Microbiol. 2018, 283, 59-64. [CrossRef] [PubMed]

12. Koné, K.M.; Douamba, Z.; De Halleux, M.; Bougoudogo, F.; Mahillon, J. Prevalence and diversity of the thermotolerant bacterium Bacillus cytotoxicus among dried food products. J. Food Prot. 2019, 82, 1210-1216. [CrossRef] [PubMed]

13. King, N.J.; Whyte, R.; Hudson, J.A. Presence and significance of Bacillus cereus in dehydrated potato products. J. Food Prot. 2007, 70, 514-520. [CrossRef] [PubMed]

14. Contzen, M.; Hailer, M.; Rau, J. Isolation of Bacillus cytotoxicus from various commercial potato products. Int. J. Food Microbiol. 2014, 174, 19-22. [CrossRef]

15. Cavello, I.; Urbieta, M.S.; Cavalitto, S.; Donati, E. Bacillus cytotoxicus isolated from a pristine natural geothermal area reveals high keratinolytic activity. Microorganisms 2020, 8, 796. [CrossRef] [PubMed]

16. Glasset, B.; Herbin, S.; Guillier, L.; Cadel-Six, S.; Vignaud, M.; Grout, J.; Pairaud, S.; Michel, V.; Hennekinne, J.; Ramarao, N.; et al. Bacillus cereus-induced food-borne outbreaks in France, 2007 to 2014: Epidemiology and genetic characterisation. Eurosurveillance 2016, 21. [CrossRef]

17. Rouzeau-Szynalski, K.; Stollewerk, K.; Messelhäusser, U.; Ehling-Schulz, M. Why be serious about emetic Bacillus cereus: Cereulide production and industrial challenges. Food Microbiol. 2020, 85. [CrossRef] [PubMed]

18. Castiaux, V.; Liu, X.; Delbrassinne, L.; Mahillon, J. Is Cytotoxin K from Bacillus cereus a bona fide enterotoxin? Int. J. Food Microbiol. 2015, 211, 79-85. [CrossRef] 
19. Ehling-Schulz, M.; Guinebretiere, M.H.; Monthán, A.; Berge, O.; Fricker, M.; Svensson, B. Toxin gene profiling of enterotoxic and emetic Bacillus cereus. FEMS Microbiol. Lett. 2006, 260, 232-240. [CrossRef] [PubMed]

20. Moravek, M.; Dietrich, R.; Buerk, C.; Broussolle, V.; Guinebretière, M.H.; Granum, P.E.; Nguyen-The, C.; Märtlbauer, E. Determination of the toxic potential of Bacillus cereus isolates by quantitative enterotoxin analyses. FEMS Microbiol. Lett. 2006, 257, 293-298. [CrossRef]

21. Jeßberger, N.; Krey, V.M.; Rademacher, C.; Böhm, M.E.; Mohr, A.K.; Ehling-Schulz, M.; Scherer, S.; Märtlbauer, E. From genome to toxicity: A combinatory approach highlights the complexity of enterotoxin production in Bacillus cereus. Front. Microbiol. 2015, 6. [CrossRef]

22. Jessberger, N.; Kranzler, M.; Da Riol, C.; Schwenk, V.; Buchacher, T.; Dietrich, R.; Ehling-Schulz, M.; Märtlbauer, E. Assessing the toxic potential of enteropathogenic Bacillus cereus. Food Microbiol. 2019, 84. [CrossRef]

23. Riol, C.D.; Dietrich, R.; Märtlbauer, E.; Jessberger, N. Consumed foodstuffs have a crucial impact on the toxic activity of Enteropathogenic Bacillus cereus. Front. Microbiol. 2018, 9. [CrossRef] [PubMed]

24. Beecher, D.J.; Wong, A.C.L. Improved purification and characterization of Hemolysin BL, a hemolytic dermonecrotic vascular permeability factor from Bacillus cereus. Infect. Immun. 1994, 62, 980-986. [CrossRef] [PubMed]

25. Guinebretiere, M.H.; Fagerlund, A.; Granum, P.E.; Nguyen-The, C. Rapid discrimination of cytK-1 and cytK-2 genes in Bacillus cereus strains by a novel duplex PCR system. FEMS Microbiol. Lett. 2006, 259, 74-80. [CrossRef] [PubMed] 